Przegląd Badań Edukacyjnych Educational Studies Review

ISSN 1895-4308

nr 19 (2/2014), s. 129-148

METAANALIZY

BADAŃ

EDUKACYJNYCH

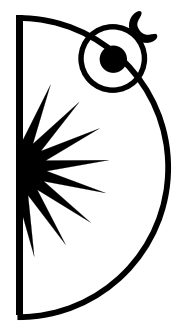

Dorota Pankowska

Uniwersytet Marii Curie-Skłodowskiej w Lublinie, e-mail: dorotapankowska@wp.pl

\title{
Kwestia płci i rodzaju - „nieobecny dyskurs” w kształceniu nauczycieli
}

DOI: http://dx.doi.org/10.12775/PBE.2014.025

\section{The Question of Sex and Gender: "The Non-existent Discourse" in the Teacher Training}

\begin{abstract}
The article analyses the non-existence of gender issues in the programmes and practice of teacher education in the context of the discussion which takes place in Poland. In the first part, the author provides a review of Polish pedagogical research concerning sex and gender; the second part focuses on the analysis of teacher education programmes, paying special attention to the aforementioned issues; the third part reflects on the consequences of teachers' unfamiliarity with parity education.
\end{abstract}

Key words: gender, pedagogical research, teachers' education

Tytuł artykułu nawiązuje z jednej strony do wyrażenia „kwestia kobieca”, które w XIX w. określało nowe pole problemowe, jakie wyłoniło się w debacie społecznej w wyniku aspiracji emancypacyjnych kobiet, z drugiej zaś - do cyklu publikacji z początku lat 90. Nieobecne dyskursy pod redakcją Zbigniewa Kwiecińskiego (1991 i kolejne tomy), które miały na celu ukazanie ważnej problematyki edukacyjnej obecnej w krajach zachodnich, a przemilczanej w polskiej pedagogice ze względów ideologicznych.

Zgodnie z definicją słownikową (Szymczak, 1978, s. 1100) „kwestia” to: „sprawa wymagająca rozstrzygnięcia, załatwienia; zagadnienie, problem”, 
a częste wyrażenia frazeologiczne z nią związane - „kwestia drażliwa, paląca, zawiła, skomplikowana" wskazują i na złożoność danego zagadnienia i na kontrowersje z nim związane. Wydawałoby się, że w Polsce w XXI w., po kilkudziesięciu latach tzw. realnego socjalizmu, po przełomie ustrojowym w $1989 \mathrm{r}$. i prawie 10-letniej przynależności do Unii Europejskiej, sprawa równościowego traktowania obu płci nie powinna budzić wątpliwości.

Ponadto problematyka gender/rodzaju, a więc związana z funkcjonowaniem społeczno-kulturowego wymiaru ról płciowych, stała się w ciagu dwudziestu kilku ostatnich lat intensywnie eksplorowanym przedmiotem badań w naukach społecznych i humanistycznych; w tym okresie powstało już tysiące publikacji na ten temat. Można by zatem przypuszczać, że przynajmniej teoretyczna refleksja odnosząca się do gender nie powinna budzić szczególnych emocji, a jedynie zachęcać do intensyfikowania zmian w zakresie praktyki społecznej, takich jak tworzenie warunków do rzeczywistego równouprawnienie kobiet i mężczyzn na rynku pracy, wprowadzanie parytetów w polityce czy zachęcanie mężczyzn do większego angażowania się w wychowanie dzieci. Doświadczenia ostatnich ${ }^{1}$ miesięcy pokazują jednak, że nie dla wszystkich jest to problematyka znana i „oswojona”. Świadczy o tym pojawienie się dyskursie publicznym określenia ,ideologia gender" wraz z jej interpretacją i konsekwencjami. A że we wszelkich zmianach społecznych ma, a przynajmniej powinna mieć, znaczący udział edukacja, w dalszej części artykułu przedstawię:

- w jaki sposób obecna jest problematyka gender w refleksji i badaniach pedagogicznych,

- na czym polega jej nieobecność w praktyce kształcenia nauczycieli,

- jakie konsekwencje powodują wieloletnie zaniedbania w zakresie edukacji równościowej.

\section{Problematyka płci i rodzaju w teorii i badaniach pedagogicznych}

Zgodnie z definicją przyjętą w naukach społecznych, angielskie słowo gender (w języku polskim: rodzaj), w odróżnieniu od słowa sex, oznaczającym płeć biologiczną, odnosi się do płci społeczno-kulturowej. Jest to „zespół atrybutów, postaw, ról społecznych i zachowań przypisanych mężczyźnie lub kobiecie przez szeroko rozumianą kulturę" (Bem, 2000, s. 9). Rozróżnienie to okazało się konieczne, aby uchwycić udział społeczeństwa, procesów socjalizacji i in-

\footnotetext{
${ }^{1}$ Ostateczna wersja tekstu została ukończona w połowie kwietnia $2014 \mathrm{r}$.
} 
kulturacji w przyswajaniu definicji kobiecości i męskości oraz kształtowania się kobiecych i męskich ról społecznych, zarówno na poziomie makrospołecznym (system ról płciowych/rodzajowych) oraz osobowościowym (osiaganie tożsamość płciowej i rodzajowej, przyswajanie i pełnienie ról społecznych przez kobiety i mężczyzn). Badanie $\mathrm{i}$ analizowanie tych zagadnień wiąże się $\mathrm{z}$ oceną konsekwencji funkcjonowania systemu ról rodzajowych dla jednostek i społeczeństw, co - w krajach zachodnich - stało się podstawą do wprowadzania polityki równościowej w różnych sferach życia. Należy jednak odróżniać praktyki mające na celu wyrównywanie praw oraz szans życiowych i możliwości rozwoju kobiet i mężczyzn (tzw. gender mainstreaming) od płci społeczno-kulturowej jako faktu społecznego oraz przedmiotu (i paradygmatu) badań społecznych i humanistycznych.

Problematyka płci i rodzaju jest ze swej natury interdyscyplinarna, ale można wyróżnić prace pedagogiczne, w których autorzy i autorki prowadzili własne badania na ten temat. I choć w polskiej pedagogice, w porównaniu z socjologia, psychologią czy kulturoznawstwem i naukami o literaturze, nie tak wiele miejsca poświęcano do tej pory zagadnieniom związanym z szeroko pojmowaną problematyką gender, zwłaszcza w zakresie empirycznych eksploracji, dorobek w tym zakresie jest zauważalny.

Można wyodrębnić główne obszary związane z obecnością problematyki gender w pedagogice: edukacja jako system, stereotypy płci i ról rodzajowych, socjalizacja do ról rodzajowych, programy edukacyjne, kształcenie nauczycieli.

\section{Edukacja jako system}

Analiza systemu edukacji w kontekście równości vs. nierówności dotyczy zarówno warunków kształcenia, jak i szans oraz możliwości stwarzanych przez edukację dla obu płci. Przedmiotem refleksji i badań pedagogicznych w tym zakresie były więc zarówno jawne, jak i ukryte aspekty szkoły lub systemu oświatowego jako całości, w tym na przykład uwarunkowania i konsekwencje feminizacji zawodu nauczyciela, przejawów seksizmu, konsekwencji utrwalania stereotypizacji płciowej. W tym obszarze powstało wiele analiz krytycznych, wykorzystujących dorobek teoretyczny i badawczy krajów, w których dużo wcześniej niż w Polsce eksplorowano te obszary, ale odwołujących się do polskiej rzeczywistości edukacyjnej. Wśród tego typu prac można wymienić publikacje Ewy Muszyńskiej (2004), Doroty Pankowskiej (2002, 2005a), Marioli Chomczyńskiej-Miliszkiewicz (2002), Marioli Chomczyńskiej-Rubacha (2011a) czy Krzysztofa Konarzewskiego (2004). 
Bardziej szczegółowo kwestią równości w kontekstach edukacyjnych zajmowały się Eva Zamojska (2010), Agnieszka Gromkowska-Melosik (2011) czy Lucyna Kopciewicz $(2007,2009)$, a uwarunkowaniami i znaczeniem feminizacji zawodu nauczycielskiego - Iwona Chmura-Rutkowska (2004) oraz socjolożki - Małgorzata Fuszara (2007) i Karina Jankowska (2007).

\section{Funkcjonowanie stereotypów płciowych, ich przejawów w systemie edukacji oraz skutków}

Stereotypy płciowe/rodzajowe odgrywają szczególną rolę $\mathrm{w}$ generowaniu nierówności płciowych, ponieważ są to silnie utrwalone w świadomości społecznej przekonania, odnoszące się zarówno do treści ról społecznych kobiet i mężczyzn (zakres praw i obowiązków, rodzaj odpowiednich zajęć), jak i antynomicznych - cech osobowości, warunkowanych przynależnością do płci biologicznej (Brannon, 2002, s. 240). Przyjmując terminologię Sandry Bem (2000, s. 15-17), wyrażają one pryzmaty rodzaju, czyli jawne i ukryte założenia dotyczące płci (sex $i$ gender), będące podstawą i zasadą społecznego systemu ról - zarówno w aspekcie normatywnym, jak i praktycznym. Stereotypy odzwierciedlają zatem zarówno polaryzację rodzajową i esencjalizm biologiczny, jak i - na bardziej ukrytym poziomie - androcentryzm, stanowiąc podstawę nierówności płci.

W tej sytuacji nie dziwi, że wiele badań pedagogicznych dotyczyło obrazów systemu ról płciowych i utrwalania stereotypów kobiecości i męskości w programach kształcenia i treściach podręczników (Chomczyńska-Rubacha, 2011b; Chomczyńska-Rubacha, Pankowska, 2011), zwłaszcza do edukacji wczesnoszkolnej (m.in.: Kalinowska, 1995; Chlebio-Abed, Klimczak-Ziółek, 2004; Dymus, 2004; Pankowska, 2009a), w zakresie przygotowania do życia w rodzinie (m.in.: Chomczyńska-Miliszkiewicz, 2000; Skowrońska, 2004; Pauluk, 2006), rzadziej w innych (np. Świderska, Lebiedzik, 2004). Obecnie realizowany jest bardzo duży, ogólnopolski projekt badawczy „Gender w podręcznikach"2, zainicjowany przez Iwonę Chmurę-Rutkowską z Uniwersytetu Adama Mickiewicza w Poznaniu, którego celem jest dokonanie analizy i rekonstrukcji treści podstaw programowych oraz wszystkich podręczników zatwierdzonych dla szkół do wszystkich przedmiotów nauczania pod kątem prezentowanych i promowanych w nich wzorców kobiecych i męskich ról społecznych. Warto zaznaczyć, że projekt jest bardzo starannie przygotowywany metodologicznie,

${ }^{2}$ http://www.gender-podreczniki.pl/home. 
gdyż diagnoza ma być oparta na wspólnie wypracowanym schemacie analizy treści.

Innym przedmiotem badań, odnoszącym się do funkcjonowania stereotypów rodzajowych w edukacji, są postawy nauczycieli i nauczycielek: ich schematy poznawcze dotyczące kobiecych i męskich ról płciowych i stereotypów rodzajowych, oczekiwania i zachowania wobec uczniów i uczennic. Do najważniejszych publikacji $\mathrm{w}$ tym zakresie należą prace Lucyny Kopciewicz (2004, 2011), Renaty Szczepanik (2004, 2009), Eżbiety Górnikowskiej-Zwolak (2004). Do wyjątków na razie należą badania, które analizują różne aspekty funkcjonowania nauczycielek i nauczycieli w zawodzie w zależności od poziomu rozwoju ich roli rodzajowej (Chomczyńska-Rubacha, Rubacha, 2007).

Pojawiają się także badania na temat udziału stereotypów płciowych w postrzeganiu kobiecych i męskich ról przez dzieci i młodzież (np. Pietryczuk, 2011; Drost-Rudnicka, 2012), które wiążą się z kolejnym polem badań, czyli socjalizacją rodzajową i jej efektami.

\section{Socjalizacja do ról rodzajowych}

Studia i empiryczne badania pedagogiczne odnoszące się do socjalizacji do ról rodzajowych można podzielić na dwie grupy. Pierwsza z nich dotyczy socjalizacji widzianej „,z zewnątrz”, czyli oddziaływań różnych agend socjalizacji. Można tu zaliczyć prace, które ujmują całościowo przekazy socjalizacyjne kierowane do dzieci i młodzieży na temat istoty kobiecości i męskości, wzorców ról i stereotypów rodzajowych (np. Chomczyńska-Miliszkiewicz, 2002, s. s. 106181; Pankowska, 2005a, s. 65-104), jak również różnych źródeł wpływów3:

- języka (Karwatowska, Szpyra-Kozłowska, 2005; Bochno, 2009);

- tekstów kultury i mediów (Melosik, 2010), zwłaszcza prasy (np. Kowalczyk, 2002; Mandal, 2000, s. 34-48), telewizji (Radkiewicz, 2002; Desperak, 2002, 2006), literatury dla dzieci i młodzieży (np. Zierkiewicz, 2004; Cackowska, 2006; Zierkiewicz, Łysak, 2006);

- przedszkola (np. Gawlicz, 2009; Kamińska-Berezowska, Klimczak-Ziółek, 2007)

- szkoły (np. Chomczyńska-Rubacha, 2004; Karkowska, 2006);

- grupy rówieśniczej (Łaciak, 1998; Wójtewicz, 2009);

- kościoła (Górnikowska-Zwolak, Rajca, 2006).

${ }^{3}$ Nie wszystkie teksty są autorstwa pedagogów, jednak zostały ujęte ze względu na przedmiot badań. 
Druga grupa prac teoretyczno-badawczych poświęcona jest socjalizacji postrzeganej „od wewnątrz”, czyli z perspektywy podmiotu poddawanego oddziaływaniom socjalizacyjnym. Próbuje się w nich uchwycić proces tworzenia się tożsamości rodzajowej i rozwoju indywidualnej koncepcji roli, poznać jego uwarunkowania, mechanizmy i konsekwencje. Autorki i autorzy często odwołują się w swoich badaniach do różnych podstaw teoretycznych, m.in. koncepcji E. H. Eriksona (Chmura-Rutkowska, Ostrouch, 2007), J. H. Block (Chomczyńska-Miliszkiewicz, 2002), Bourdieu (Kopciewicz, 2007, 2009), J. M. Marcii (Cuprjak, 2007), S. Bem (Pankowska, 2006), analizy transakcyjnej (Pankowska, 2007). Pracą, która w najbardziej pogłębiony, a jednocześnie wielowymiarowy sposób krytycznie analizuje teorie wyjaśniające praktykę edukacji rodzajowej (społeczno-poznawcza teoria rozwoju płci kulturowej, teoria tożsamości płciowej i schematów płci, teorie ewolucjonistyczne, odtwarzania struktury społecznej, poststrukturalistyczne), jest książka Chomczyńskiej-Rubacha Pteć i szkoła. Od edukacji rodzajowej do pedagogiki rodzaju (2011a).

\section{Programy edukacyjne}

Kolejny nurt zainteresowań pedagogiki problematyką płci społeczno-kulturowej wiąże się $\mathrm{z}$ tworzeniem $\mathrm{i}$ wprowadzaniem $\mathrm{w}$ życie programów edukacyjnych, przy czym niektóre z nich mają charakter przede wszystkim edukacyjno-rozwojowy, koncentrując się zwłaszcza na dostarczaniu młodym ludziom wiedzy, umożliwiającej rozumienie społecznych uwarunkowań kształtowania ról rodzajowych, uwrażliwieniu na przekazy socjalizacyjne czy pomoc w tworzeniu własnej koncepcji męskiej lub kobiecej roli opartej na autonomicznych wyborach. Do takich programów można zaliczyć propozycję Doroty Pankowskiej (2005b, 2008), z której nauczyciele i wychowawcy mogą korzystać, tworząc własne programy działań wychowawczych z tego zakresu, dostosowane do określonych grup uczestników, czasu i warunków, oraz Izy Desperak (2009), która organizowała i prowadziła warsztaty wrażliwości genderowej nie tylko do młodzieży, ale też dla nauczycieli, edukatorów i trenerów. Do tej grupy należy też poradnik dla nauczycieli Równościowe przedszkole 4 Anny Dzierzgowskiej, Joanny Piotrowskiej i Ewy Rutkowskiej, określany przez autorki jako „metaprogram”, wskazujący działania osłabiające oddziaływanie stereotypowych przekazów socjalizacyjnych w środowisku przedszkolnym i świadomości dzieci.

\footnotetext{
${ }^{4}$ www.bezuprzedzen.org/doc/rownosciowe_przedszkole_program.pdf.
} 
Inny rodzaj programów i materiałów edukacyjnych można określić jako równościowe i antydyskryminacyjne, opracowywane $\mathrm{i}-\mathrm{w}$ węższym lub szerszym zakresie wprowadzane w życie - głównie przez organizacje pozarządowe i środowiska feministyczne (niekoniecznie pedagogów), realizowane często w ramach projektów emancypacyjnych współfinansowanych z Europejskich Funduszy Społecznych „Kapitał ludzki”. Choć również oparte są na poszerzaniu wiedzy na temat płci społeczno-kulturowej i budzeniu wrażliwości na jej znaczenie dla życia jednostki i społeczeństwa, to ich podstawowym celem jest zachęcanie do przełamywania stereotypowego podejścia do ról rodzajowych, co ma skutkować zwiększaniem szans kobiet na rynku pracy (np. wspieranie zainteresowań dziewcząt naukami ścisłymi), przeciwdziałaniu przemocy wobec kobiet i dzieci (w tym seksualnej), zwiększaniu asertywności w kontaktach interpersonalnych, promowaniu większego zaangażowania mężczyzn w życie rodzinne itp. Są nastawione, w dalszej perspektywie, na zmianę społeczną niwelujaca praktyki dyskryminacyjne i seksistowskie wobec obu płci. W tej grupie programów najbardziej znany jest program zajęć dla dziewcząt Anny Wołosik (2009) oraz poradniki dla nauczycielek i nauczycieli: Ewy Majewskiej i Ewy Rutkowskiej (2007), poświęcony różnym aspektom edukacji antydyskryminacyjnej (w tym ze względu na płeć), czy opracowany pod redakcją Beaty Stępień i Aliny Synakiewicz (2008), ukierunkowany na przeciwdziałanie przemocy i przemocy seksualnej wobec dziewcząt.

\section{Kształcenie nauczycieli}

Okazuje się, że dość już znaczący, choć nadal niewyczerpujący, dorobek badawczy pedagogiki dotyczący problematyki płci społeczno-kulturowej w niewielkim stopniu odnosi się do analizowania czy praktycznych zastosowań w obszarze kształcenia nauczycieli. Spośród nielicznych prac, będących krytycznymi analizami praktyki kształcenia nauczycieli w szkołach wyższych, można wymienić publikacje Marioli Chomczyńskiej-Rubacha (2010), Doroty Klus-Stańskiej (2010) i Renaty Szczepanik (2010). Jeszcze mniej licznie reprezentowane są próby badań nad skutecznością oddziaływań edukacyjnych w zakresie zmian uwewnętrznionych stereotypów płci wśród przyszłych nauczycieli (Chomczyńska-Rubacha, 2006). W publikacjach pedeutologicznych nie widać też raportów $\mathrm{z}$ wdrażania różnych programów poświęconych problematyce gender. Jak zatem wygląda praktyka kształcenia i doskonalenia nauczycieli w tym zakresie? 


\section{Problematyka gender w praktyce kształcenia nauczycieli}

System nabywania kwalifikacji zawodowych nauczycieli w Polsce regulowany jest przez standardy kształcenia nauczycieli określane przez Ministerstwo Nauki i Szkolnictwa Wyższego. Obecnie obowiązuje Rozporządzenie Ministra Nauki i Szkolnictwa Wyższego w sprawie standardów ksztatcenia przygotowujacego do wykonywania zawodu nauczyciela z 12.01.2012 r., które określa model i plan kształcenia nauczycieli w uczelniach wyższych, szczegółowe efekty oraz treści programowe.

Analiza efektów i treści programowych zawartych w tym dokumencie wyraźnie wskazuje, że są one „niewrażliwe na rodzaj”. Świadczy o tym nie tylko androcentryczny język, który uwzględnia jedynie rodzaj męski (nauczyciel, uczeń) lub męskoosobowy w liczbie mnogiej (nauczyciele, uczniowie), ale przede wszystkim brak jakichkolwiek odniesień do płci w efektach i treściach kształcenia. $Z$ jednej strony może to świadczyć o przestrzeganiu zasady powszechności efektów kształcenia, z drugiej jednak, nie dostarczając wiedzy na temat różnych aspektów nierówności w sferze edukacji i ich uwarunkowań, przekreśla szansę na stopniowe eliminowanie niekorzystnych praktyk socjalizacyjnych ze szkół.

W treściach kształcenia w module psychologiczno-pedagogicznym można znaleźć kilka haseł, które - przynajmniej potencjalnie - mogą zawierać treści odnoszące się do płci społeczno-kulturowej:

- w p. 1.7 - „Szkoła jako instytucja wychowawcza”: Ukryty program szkoty;

- w p. 2.3.1 - „Sylwetka rozwojowa ucznia w okresie adolescencji i wczesnej dorosłości”: Rozwój ...psychoseksualny ...; Krystalizowanie się tożsamości; Identyfikacja z nowymi rolami spotecznymi;

- w p. 2.3.3 - „Kontakty społeczne ucznia”: Koleżeństwo, przyjaźń, zwiqzek partnerski, miłość.

To jednak, czy nauczyciele akademiccy wykorzystają te możliwości zależy jedynie od nich. O ukrytym programie szkoły można bowiem mówić, pomijając sprawę marginalizowania kobiet $\mathrm{w}$ treściach kształcenia, utrwalania stereotypów poprzez przekazy w podręcznikach czy różnych form seksizmu stosowanych $\mathrm{w}$ systemie edukacji. Z kolei w ramach dwóch ostatnich zagadnień można albo zwracać uwagę na współczesne przemiany ról rodzajowych i ich znaczenie dla rozwoju jednostek, albo utrwalać stereotypy i wzmacniać tradycyjne podejście do ról płciowych, tak jak to się dzieje w większości materiałów edukacyjnych do wychowania do życia w rodzinie (zob. np. Chomczyńska-Rubacha, 2000; Skowrońska, 2004). 
Standardy kształcenia nauczycieli nie stanowią zatem narzędzia do wzmacniania świadomości dotyczącej implikacji istnienia płci społeczno-kulturowej ani nauczycieli akademickich, ani kształconych przez nich nauczycieli. A znaczna ilość zarówno efektów kształcenia, jak i treści określonych w standardach w stosunku do czasu zajęć przeznaczonych na realizację tego modułu utrudnia wprowadzanie tych zagadnień do programów zajęć, nawet jeśli kształcący studentów czują potrzebę ich wprowadzenia. Na podstawie własnych doświadczeń wiem, jakie jest to trudne, ponieważ włączenie problematyki gender oznacza pominięcie lub zmarginalizowanie innego rodzaju wiedzy i umiejętności, kluczowych dla wykonywania zadań dydaktyczno-wychowawczych przez nauczyciela.

Pewną szansą są studia podyplomowe lub inne formy doskonalenia nauczycieli, jednak nie poddano systematycznej analizie, w jakim stopniu i zakresie są one wykorzystywane. Sądząc z opracowań współautorów raportu „Wielka nieobecna - o edukacji antydyskryminacyjnej w systemie edukacji formalnej w Polsce. Raport z badań"5 (Chustecka, 2011, s. 27-35; Pawlegga, 2011a, s. 36-41, 2011b, s. 42-59, Teutsch, 2011, s. 72-90) zarówno na studiach podyplomowych realizowanych na uczelniach wyższych, jak i na różnego typu kursach i szkoleniach oferowanych przez ośrodki doskonalenia zawodowego nauczycieli, problematyka dotycząca płci społeczno-kulturowej, (nie)równości w edukacji itp. jest reprezentowana bardzo nielicznie. Można przypuszczać, że zagadnienia te pojawiają się okazjonalnie w programach studiów podyplomowych czy innych form doszkalania nauczycieli, zwłaszcza tych, które są dofinansowane z funduszy europejskich, ale zwykle jednak ograniczają się do kilkugodzinnych zajęć (tak było w kilku przypadkach studiów realizowanych na UMCS w Lublinie). Niewątpliwie warto by zbadać pod tym kątem programy studiów i sylabusy przedmiotów realizowane zarówno na wydziałach kształcących nauczycieli, jak i na kierunkach pedagogicznych, aby mieć orientację w rzeczywistej dostępności wiedzy o płci społeczno-kulturowej w ramach uczelni wyższych. Dotychczasowe doświadczenia i nieliczne analizy wskazuja, że jest ona niewielka.

\section{Konsekwencje „niewrażliwej na płeć" edukacji nauczycieli}

Całkowity brak odnoszenia się do płci społeczno-kulturowej w standardach kształcenia nauczycieli można interpretować dwojako. Z jednej strony nieobec-

\footnotetext{
${ }^{5}$ Publikacja dostępna na stronie: http://www.tea.org.pl/userfiles/file/Wielka_nieobecna_raport.pdf.
} 
ność tych treści można traktować jako neutralność rodzajową, która ma wyrażać przekonanie o dążeniu edukacji do równości płci i nie zachęcać do różnicowania oddziaływań wobec uczennic i uczniów. Taka strategia jednak może być skuteczna w sytuacji, gdy w rzeczywistości społecznej płeć nie jest kategoria różnicującą ludzi i ich funkcjonowanie, kobiety i mężczyźni są jednostkami psychologicznie androgynicznymi, a system ról rodzajowych nie jest oparty na pryzmatach rodzaju - polaryzacji, esencjalizmie biologicznym oraz androcentryzmie (zob. Bem, 1994, 2000), które generują stereotypizację płciowa, a w konsekwencji seksizm i możliwość dyskryminacji. W sytuacji, gdy takie społeczeństwo jest utopią, milczenie na temat rodzaju w kształceniu nauczycieli jest tylko pozornie prorównościowe, gdyż $\mathrm{w}$ istocie powoduje działanie ukrytego programu edukacji.

Rezygnacja z poszerzania świadomości nauczycieli dotyczącej funkcjonowania systemu ról rodzajowych i ich skutków rozwojowych i społecznych prowadzi do posługiwania się przez nich wiedzą potoczną i indywidualnymi schematami poznawczymi, co zwykle oznacza uleganie stereotypom płci w myśleniu i działaniu. Taka sytuacja z kolei może powodować:

- wzmacnianie ukrytych nierówności w edukacji, m.in. marginalizacja lub wykluczanie kobiet z przestrzeni symbolicznej, np. w treściach kształcenia (Pankowska, 2009b) oraz seksizmu indywidualnego i kulturowego (zob. Unger, Saundra, 2002) przejawianego w działaniach nauczycieli/ ek i uczniów/uczennic;

- niewykorzystanie szansy na wszechstronny rozwój uczniów i uczennic poprzez wzmacnianie stereotypowo określonych wzorców kobiecości i męskości przy jednoczesnym zaniedbywaniu kształtowania innych dyspozycji (np. u dziewcząt zainteresowań naukami ścisłymi, umiejętności technicznych, niezależności i samodzielności myślenia; u chłopców natomiast - empatii i innych kompetencji emocjonalnych i społecznych);

- pozostawianie bez wsparcia młodzieży w radzeniu sobie z „napięciami” w procesie kształtowania indywidualnych ról rodzajowych, które wynikają ze sprzeczności między utrwalanym w procesie socjalizacji stereotypowym wizerunkom kobiecości i męskości a wymaganiami współczesnego świata i przemian, jakie zaszły w rozwiniętych społeczeństwach demokratycznych;

- niewystarczającą realizację emancypacyjnej funkcji edukacji, zgodnie z którą szkoła nie tylko powinna nadążać za zmianami społecznymi, ale też je ukierunkowywać i w pewien sposób promować, aby przygotowywać dzieci i młodzież do funkcjonowania w przyszłości; 
- swoistą „bezbronność” nauczycieli i uczniów/uczennic wobec demagogicznych przekazów i projektów politycznych, ponieważ brak wiedzy i krytycznej refleksji powoduje dezorientację, a w konsekwencji podatność na wpływy, zwłaszcza jeśli ich źródłem są autorytety.

Ten ostatni problem był przez lata w pewien sposób „uśpiony”, jednak w ostatnim czasie zauważalne jest ,zawłaszczanie dyskursu” dotyczącego problematyki gender i bezpodstawne jej ideologizowanie przez niektóre środowiska silnie obecne w przestrzeni publicznej (przede wszystkim Kościół katolicki oraz polityczne środowiska konserwatywne). Ideologizowanie problematyki związanej z płcią społeczno-kulturową polega na:

- wprowadzeniu nacechowanego ujemnie terminu ,ideologia gender";

- fałszowaniu rzeczywistości przez przypisywanie pojęciu gender błędnego znaczenia i niewłaściwych ,pól problemowych” (edukacji seksualnej w modelu liberalnym, utożsamianiu z transseksualizmem, homoseksualizmem, radykalnym feminizmem jako działaniem społecznym itp.);

- ugruntowywaniu problematyki społecznej, jaką jest fakt istnienia płci społeczno-kulturowej (gender), w kontekstach religijnych i moralnych oraz odwoływanie się do autorytetu Kościoła;

- narzucaniu języka emocji i konfrontacji;

- tworzeniu atmosfery zagrożenia.

Jak to wygląda w praktyce? Oto przykład - kilka cytatów z artykułu z czasopisma katolickiego „Ku Wspólnocie”, w którym autorka cytuje autorytety naukowe i religijne jednocześnie, bo wypowiedzi księży profesorów (wszystkie za: Miturska, 2013):

„Trzeba wiedzieć, że gender jest wyrazem buntu przeciw Bogu i przeczy chrześcijańskiej wizji człowieka oraz rozumowi i dlatego jest wielkim zagrożeniem dla wszystkich. Potwierdził to m.in. wybitny filozof KUL ks. prof. A. Maryniarczyk, nazywając tę ideologię «pełzającym totalitaryzmem», który jak marksizm, leninizm i stalinizm prowadzi w naszej Ojczyźnie agresywną walkę z wartościami na wszystkich polach życia społeczeństwa [...]”;

„Jeszcze dokładniej wyjaśnił istotę omawianego zjawiska wybitny jego znawca ks. prof. Dariusz Oko z Krakowa: «Gender - to ideologia totalitarna, wywodząca się z lewackiego ateizmu (...) Ludzie będący zaciekłymi wrogami Boga stają się najbardziej gorliwymi sługami Szatana i to on jest zasadniczym źródłem ich myślenia (...) Inne źródła tej ideologii to walczący geje, fanatyczne feministki i często lesbijki (...) masoneria oraz grupa miliarderów amerykańskich (...) genderyzm deprawuje i ateizuje poprzez seksualizację (...) Jest jeszcze gorszy od bolszewizmu, bo niszczy samo człowieczeństwo 
i rodzinę» [...]" (wielokropki w okragłych nawiasach zgodne z oryginalnym tekstem);

„Genderyzm ostro potępiają obrońcy życia Pro life oraz wiele organizacji i środowisk rozumiejących niegodziwe cechy i działania wyznawców tej agresywnej ideologii".

Warto nadmienić, że kiedy zaczęłam pisać ten tekst w listopadzie 2013 r., cytowany artykuł wydawał się dość odosobniony, tymczasem - gdy kończę go pisać - w kwietniu 2014 r. w prawicowych i katolickich mediach (w tym na internetowych forach) można znaleźć setki wypowiedzi w takim duchu. Ludzie mający świadomość, czym jest płeć społeczno-kulturowa, a czym nie jest, będa potrafili krytycznie ocenić takie przekazy. Skoro jednak nauczyciele nie maja tej świadomości i nie uczą o tym uczniów, obszary niewiedzy są powszechne.

Wydawałoby się, że medialna wrzawa na temat ,ideologii gender” jest chwilowa i szybko przeminie. Jednak aktywność środowisk konserwatywnych i Kościoła katolickiego w tym zakresie nie polega jedynie na przekazywaniu pewnych treści i wywoływaniu zamętu poznawczego w umysłach ludzi. Idą za tym działania o charakterze politycznym. Przykładem może być interpelacja posłanki Elżbiety Rafalskiej (nr $17650 \mathrm{z}$ dnia 23.05 .2013 r.) ${ }^{6} \mathrm{~W}$ sprawie programu „Równościowe przedszkole”, skierowana do ministra edukacji narodowej czy interpelacje radnych w samorządach. O ile jednak posłanka otrzymała odpowiedź merytoryczną, w której wskazano z jednej strony zgodność tego programu z przepisami ministerialnymi, z drugiej strony zaś brak wychowawczych zagrożeń z tytułu jego ewentualnej realizacji w placówkach, o tyle na poziomie samorządu sprawa może przybierać inny obrót. Tak się stało w Lublinie, gdy w wyniku interpelacji radnego Tomasza Pituchy, dotyczącej wprowadzania do placówek oświatowych programów zawierających elementy ,ideologii gender", Wydział Oświaty i Wychowania Urzędu Miasta Lublin zwrócił się z zapytaniem do wszystkich przedszkoli i szkół podstawowych, czy są w nich realizowane takie (lub inne) programy, wymieniając „Równościowe przedszkole”, „NAWIGATOR”, „Kompasik”, „Edukacja bez tabu”, „Równa szkoła - edukacja wolna od dyskryminacji” (pismo z 31.10.2013 r., nr OW-PP4424.30.2013) i wyznaczając termin odpowiedzi do 6.11.2013 r. Można przypuszczać, że takie pismo od „pracodawcy” wielu placówek realizujących bądź planujących wdrożenie programów równościowych skutecznie ich do nich zniechęci. Inny przykład to apel wiceprezydenta Radomia Ryszard Fałka z 7.01.2014 r., który zwracając się do dyrektorów i nauczycieli radomskich samorządowych placó-

${ }^{6}$ www.sejm.gov.pl/sejm7.nsf/interpelacje. 
wek oświatowych, prosi w związku ze stanowiskiem Episkopatu Polski w zakresie ,ideologii gender” „wszystkich wychowawców i pedagogów o szczególną wrażliwość i odpowiedzialność w zakresie wprowadzania pilotażowych eksperymentów w zakresie gender". Przypomina także, że w Polsce ok. 90\% społeczeństwa to katolicy, dla których stanowisko Episkopatu jest wiążące, oraz że zgodnie z ,art. 48 ust.1 Konstytucji: «Rodzice mają prawo do wychowania dzieci zgodnie z własnymi przekonaniami»", zatem zobowiązuje pracowników placówek edukacyjnych do uzyskiwania indywidualnej zgody każdego z rodziców na przekazywanie określonych treści ${ }^{7}$. I choć wypowiedź wiceprezydenta miasta to jedynie apel, który nie zakazuje wprost wprowadzania programów równościowych czy ograniczających stereotypizację płciową, to nietrudno przewidzieć reakcje wielu dyrektorów i nauczycieli.

Inną polityczną konsekwencją jest powołanie przez Solidarną Polskę zespołu parlamentarnego „Stop ideologii gender”, którego cele zakładają bezpośrednią ingerencję w system edukacji:

„[...] 2) Wypracowanie i przedstawienie organom Sejmu i Senatu oraz Rządowi Rzeczpospolitej Polskiej rozwiązań dotyczących możliwości zwalczania negatywnego wpływu ideologii gender na wychowanie dzieci.

3) Współpraca z ekspertami, psychologami oraz ośrodkami badań naukowych, stowarzyszeniami, jak również podobnymi zespołami w parlamencie Europejskim, w celu wypracowania rozwiązań, dotyczących wzmocnienia praw tradycyjnej rodziny oraz niwelowania wpływu ideologii gender na wychowanie najmłodszych. [...]

5) Monitorowanie i dokumentowanie praktycznej realizacji ideologii gender w instytucjach życia publicznego i społecznego ze szczególnym uwzględnieniem placówek oświatowych i wychowawczych"8.

Mimo iż Solidarna Polska jest niewielkim ugrupowaniem opozycyjnym, to powołanie przez nią zespołu „Stop ideologii gender”, firmowanego przez znanych polityków - Beatę Kempę i Zbigniewa Ziobro, może zachęcić i inne, bardziej wpływowe partie do podobnych działań. Powstanie tego zespołu świadczy również o tym, że wszelkie głosy ekspertów ${ }^{9}$, polityków czy oficjalne wypowiedzi minister Agnieszki Kozłowskiej-Rajewicz, Pełnomocniczki Rządu

\footnotetext{
7 Za: www.fronda.pl/a/prosze-o-szczegolna-odpowiedzialnosc..., odsłona 13.01.2014 r.

${ }^{8} \mathrm{Za}$ : www.fronda.pl/a/juz-jest-parlamentarny-zespol-stop-ideologii-gender..., odsłona 13.01.2014 r.

${ }^{9} \mathrm{~Np}$. List otwarty środowiska naukowego pedagogów zajmujących się problematyką gender z 31.01.2014 r.
} 
ds. Równego Traktowania wyjaśniające znaczenie pojęcia gender i prostujące fałszywe jego interpretacje ${ }^{10}$ są całkowicie ignorowane przez środowiska prawicowe i kościelne, nie docierając również do szerszych kręgów społecznych.

Konkludując, można powiedzieć, że konsekwencje swoistego oderwania akademickiej refleksji i debaty na temat płci społeczno-kulturowej od praktyki pedagogicznej, którego skutkiem było zaniechanie szerokiego wprowadzenia tej problematyki do systemu kształcenia nauczycieli oraz działań edukacyjnych wobec dzieci i młodzieży, mogą być poważne. $O$ ile bowiem wcześniej nauczyciele i wychowawcy nie realizowali programów wychowawczych na ten temat z uwagi na brak wiedzy i „wrażliwości genderowej” (choć materiały edukacyjne dostępne są od blisko 10 lat), o tyle obecnie mogą tym bardziej, już świadomie, powstrzymywać się od wszelkich działań kojarzących się z gender albo $\mathrm{z}$ uwagi na nabyte przekonania tak intensywnie ostatnio promowane przez środowiska konserwatywne, albo z uwagi na lęk przed konsekwencjami. Nie jest niemożliwy scenariusz rozwoju wydarzeń, w którym - przy innym układzie sił politycznych w Polsce - mogą się w niedalekiej przyszłości pojawić prawne nakazy i zakazy „unieważniające” zarówno przemiany systemu ról rodzajowych, jak i równościową politykę Unii Europejskiej.

\section{Bibliografia}

Bem S. L. (1994), Androgynia psychiczna a tożsamość ptciowa, [w:] P. G. Zimbardo, F. L. Ruch, Psychologia i życie, PWN, Warszawa.

Bem S. L. (2000), Męskość. Kobiecość. O różnicach wynikających z ptci, Gdańskie Wydawnictwo Psychologiczne, Gdańsk.

Bochno E. (2009), Stereotyp płci czy pteć języka? Szkolne interakcje komunikacyjne nauczycielek z uczennicami i uczniami, [w:] L. Kopciewicz, E. Zierkiewicz (red.): Koniec mitu niewinności? Płeć i seksualność w socjalizacji i edukacji, ENETEIA, Warszawa, s. 181-191.

Brannon L. (2002), Psychologia rodzaju, Gdańskie Wydawnictwo Psychologiczne, Gdańsk.

Cackowska M. (2006), O wybranych problemach społecznego rynku ksiażek dla dziewczynek i chtopców w Polsce i na świecie, [w:] M. Chomczyńska-Rubacha (red.), Role ptciowe. Kultura i edukacja, WSHE, Łódź, s. 55-73.

Chlebio-Abed D., Klimczak-Ziółek J. (2004), Koncepcje kobiecości i męskości w podręczni-

${ }^{10} \mathrm{~Np}$. W: http://kozlowskarajewicz.natemat.pl/85221,agnieszka-kozlowska-rajewicz-tlumaczy..., odsłona 13.01.2014 r. 
kach szkolnych dla klas pierwszych, [w:] M. Chomczyńska-Rubacha (red.), Pteć i rodzaj w edukacji, WSHE, Łódź, s. 143-154;

Chmura-Rutkowska I. (2004), Getto nauczycielek - w pułapce stereotypu. W: Płeć i rodzaj w edukacji, pod red. M.Chomczyńskiej-Rubacha, WSHE, Łódź, s.109-121.

Chmura-Rutkowska I., Ostrouch J. (2007), Mężczyźni na przełęczy życia. Studium socjopedagogiczne, Impuls, Kraków.

Chomczyńska-Miliszkiewicz M. (2000), Ukryte przekazy w podręcznikach edukacji psychoseksualnej, „Forum Oświatowe”, nr 2, s. 161-178.

Chomczyńska-Miliszkiewicz M. (2002), Edukacja seksualna w społeczeństwie współczesnym. Konteksty pedagogiczne i psychospołeczne, Wydawnictwo UMCS, Lublin 2002.

Chomczyńska-Rubacha M. (2004), Nauczycielskie i uczniowskie przekazy socjalizacyjne zwiqzane z ptciq, [w:] M. Chomczyńska-Rubacha (red.), Pteć i rodzaj w edukacji, WSHE, Łódź, s. 53-62.

Chomczyńska-Rubacha M. (2006), Wptyw działań edukacyjnych na spostrzeganie stereotypów ptciowych, [w:] M. Chomczyńska-Rubacha (red.), Role ptciowe. Kultura i edukacja, WSHE, Łódź 2006, s. 111-118.

Chomczyńska-Rubacha M. (2010), Ukryty program edukacji pedagogów i nauczycieli, „Kultura i Edukacja”, pod red. M. Chomczyńskiej-Rubacha, nr 2, s. 17-31.

Chomczyńska-Rubacha M. (2011a), Płeć i szkoła. Od edukacji rodzajowej do pedagogiki rodzaju, WN PWN, Warszawa.

Chomczyńska-Rubacha M. (2011b), Podręczniki jako przedmiot badań genderowych (feministycznych), [w:] M. Chomczyńska-Rubacha M. (red.), Podręczniki i poradniki. Konteksty, dyskursy, perspektywy, Impuls, Kraków, s. 31-48.

Chomczyńska-Rubacha M., Pankowska D. (2011), Władza, ideologia, socjalizacja. Polityczność podręczników szkolnych, [w:] M. Chomczyńska-Rubacha (red.), Podręczniki i poradniki. Konteksty, dyskursy, perspektywy, Impuls, Kraków, s. 17-30.

Chomczyńska-Rubacha M., Rubacha K. (2007), Płeć kulturowa nauczycieli. Funkcjonowanie w roli zawodowej, Impuls, Kraków.

Chustecka M. (2011), Opinia ekspertek/ekspertów o systemie kształcenia i doskonalenia nauczycieli, [w:] M. Abramowicz (red.), Wielka nieobecna - o edukacji antydyskryminacyjnej w systemie edukacji formalnej w Polsce. Raport z badań, Towarzystwo Edukacji Antydyskryminacyjnej, Warszawa, s. 27-35.

Cuprjak M. (2007), Pteć a teoria statusów tożsamości Jamesa Marcii, [w:] M. Chomczyńska-Rubacha (red.), Teoretyczne perspektywy badań nad edukacja rodzajowa, WSHE, Łódź, s. 116-121. 
Desperak I. (2002), Stereotypy kobiet $i$ ich ról społecznych $i$ zawodowych $w$ reklamie telewizyjnej, [w:] E. Zierkiewicz, I. Kowalczyk (red.), Kobiety w kulturze popularnej, Konsola, Wrocław, s. 63-74.

Desperak I. (2006), Wizerunki kobiet $w$ mass mediach i reklamie a autostereotypy, [w:] M. Chomczyńska-Rubacha (red.), Role ptciowe. Kultura i edukacja, WSHE, Łódź 2006, s. 31-42.

Desperak I. (2009), Warsztaty wrażliwości Genderowej, [w:] L. Kopciewicz, E. Zierkiewicz (red.), Koniec mitu niewinności? Płeć i seksualność w socjalizacji i edukacji, ENETEIA, Warszawa, s. 237-250.

Drost-Rudnicka M. (2012), Edukacja wczesnoszkolna a problem nierówności płci uczniowskie stereotypy postrzegania płci, [w:] N. Majchrzak, N. Starik, A. Zduniak (red.), Podmiotowość w edukacji wobec odmienności kulturowych oraz społecznych zróżnicowań, Wydawnictwo Wyższej Szkoły Bezpieczeństwa, Poznań, s. 447-456.

Dymus K. (2004), Obrazy rzeczywistości konstruowane w podręcznikach szkolnych, [w:] M. Chomczyńska-Rubacha (red.), Płeć i rodzaj w edukacji, WSHE, Łódź, s. 155-167.

Dzierzgowska A., Piotrowska J., Rutkowska E., Równościowe przedszkole, www.bezuprzedzen.org/doc/rownosciowe_przedszkole_program.pdf.

Fuszara M. (2007), Dobrze jest być rodzynkiem, czyli mężczyźni w zawodach sfeminizowanych, [w:] M. Fuszara (red.), Nowi mężczyźni? Zmieniajace się modele męskości we współczesnej Polsce, TRIO, Warszawa, s. 329-360.

Gawlicz K. (2009), Negocjowanie znaczenia kategorii płci. Pomiędzy różnicowaniem płciowym a przekraczaniem granic, [w:] L. Kopciewicz, E. Zierkiewicz (red.), Koniec mitu niewinności? Płeć i seksualność w socjalizacji i edukacji, ENETEIA, Warszawa, s. $89-118$.

Górnikowska-Zwolak E. (2004), Nauczycielskie koncepcje ról społecznych kobiety i mężczyzny - czynnik wzmacniajacy czy osłabiajacy szanse rozwojowe dziewczat $i$ chtopców?, [w:] M. Chomczyńska-Rubacha (red.), Płeć i rodzaj w edukacji, WSHE, Łódź, s. 85-91.

Górnikowska-Zwolak E., Rajca K. (2006), Poglady przedstawicieli Kościoła na temat miejsca i roli kobiet we wspótczesnym świecie - spojrzenie przez pryzmat feminizmu, [w:] M. Chomczyńska-Rubacha (red.), Role ptciowe. Kultura i edukacja, WSHE, Łódź 2006, s. 11-30.

Gromkowska-Melosik A. (2011), Edukacja i (nie)równość społeczna kobiet. Studium dynamiki dostęp, Impuls, Kraków.

Jankowska K. (2007), Mężczyźni - nauczyciele gimnazjalni i licealni, [w:] M. Fuszara (red.), 
Nowi mężczyźni? Zmieniajace się modele męskości we współczesnej Polsce, TRIO, Warszawa, s. 361-387.

Kalinowska E. (1995), Wizerunki dziewczynek i chłopców, kobiet i mężczyzn w podręcznikach szkolnych, „Kwatalnik Pedagogiczny”, 1-2.

Kamińska-Berezowska S., Klimczak-Ziółek J. (2007), Teoria ugruntowana w badaniach społecznego świata zabaw i zabawek dzieci - procedury metodologiczne, [w:] M. Chomczyńska-Rubacha (red.), Teoretyczne perspektywy badań nad edukacja rodzajowq, WSHE, Łódź, s. 167-180.

Karkowska M. (2006), Socjalizacja rodzajowa dziewczą i chłopców a ukryty program edukacji szkolnej, [w:] M. Chomczyńska-Rubacha (red.), Role ptciowe. Kultura i edukacja, WSHE, Łódź, s. 119-132.

Karwatowska M., Szpyra-Kozłowska J. (2005), Lingwistyka płci. Ona i on w języku polskim, Wydawnictwo UMCS, Lublin.

Klus-Stańska D. (2010), Infantylizujacy stereotyp nauczycielki wczesnej edukacji. W poszukiwaniu kontekstu i źródet ukrytego dyskursu ,,naszej pani”, „Kultura i Edukacja”, pod red. M. Chomczyńskiej-Rubacha, nr 2, s. 17-31.

Konarzewski K. (2004), Egzaminy zewnętrzne - czy maja płeć?, [w:] M. Chomczyńska-Rubacha (red.), Pteć i rodzaj w edukacji, WSHE, Łódź, s. 63-71.

Kopciewicz L. (2004), Schematy rodzaju (gender) w pracy pedagogicznej nauczycielek edukacji wczesnoszkolnej, [w:] M. Chomczyńska-Rubacha (red.), Płeć i rodzaj w edukacji, WSHE, Łódź, s. 75-84.

Kopciewicz L. (2007), Rodzaj i edukacja. Studium fenomenograficzne z zastosowaniem teorii społecznej Pierre'a Bourdieu, WN Dolnośląskiej Wyższej Szkoły Edukacji TWP, Wrocław.

Kopciewicz L. (2009), Edukacja jako praktyka dominacji. Udział szkoły w wytwarzaniu kapitałów rodzajowych uczennic i uczniów, [w:] L. Kopciewicz, E. Zierkiewicz (red.), Koniec mitu niewinności? Płeć i seksualność w socjalizacji i edukacji, ENETEIA, Warszawa, s. 13-28.

Kopciewicz L. (2011), Nauczycielskie poniżanie. Szkolna przemoc wobec dziewczat, Difin, Warszawa.

Kowalczyk I. (2002), Uwięziona w ciele - ideały ciała w pismach kobiecych, [w:] E. Zierkiewicz, I. Kowalczyk (red.), Kobiety w kulturze popularnej, Konsola, Wrocław, s. 17-30.

Kwieciński Z. (red.) (1991), Nieobecne dyskursy, cz. 1. Wydawnictwo UMK, Toruń.

Łaciak B. (1998), Świat społeczny dziecka, Żak, Warszawa. 


\section{METAANALIZY BADAŃ EDUKACYJNYCH}

Majewska E., Rutkowska E. (wspólpr. M. Jończy-Adamska i A. Wołosik) (2007), Równa szkoła - edukacja wolna od dyskryminacji. Poradnik dla nauczycielek i nauczycieli, Dom Współpracy Polsko-Niemieckiej, Gliwice.

Mandal E. (2000), Podmiotowe i interpersonalne konsekwencje stereotypów zwiazanych z ptciq. Wydawnictwo Uniwersytetu Śląskiego, Katowice 2000.

Melosik (2010), Tożsamość, ciało i władza w kulturze instant, Impuls, Kraków.

Miturska H. (2013), Ideologia gender - negacja Boga i poniżenie człowieka, „Ku wspólnocie", nr 3 (91), s. 5.

Muszyńska E. (2004), Warunki edukacji szkolnej dziewcząt i chłopców: różnice, ich przemiany i skutki, [w:] M. Chomczyńska-Rubacha (red.), Płeć i rodzaj w edukacji, WSHE, Łódź, s. 43-51.

Pankowska D. (2002), Dualizm ról i stereotypów ptciowych - konsekwencje edukacyjne, „Teraźniejszość. Człowiek. Edukacja”, nr 2, s. 79-92.

Pankowska D. (2005a), Wychowanie a role ptciowe, GWP, Gdańsk 2005.

Pankowska D. (2005b), Wychowanie a role ptciowe. Program edukacyjny, GWP, Gdańsk.

Pankowska D. (2006), Doświadczenia socjalizacyjne a tożsamość rodzajowa-raport z badań pilotażowych, [w:] M. Chomczyńska-Rubacha (red.), Role płciowe. Socjalizacja i rozwój, WSHE, Łódź, s. 149-157.

Pankowska D. (2007), Problematyka gender w perspektywie analizy transakcyjnej, [w:] M. Chomczyńska-Rubacha (red.), Teoretyczne perspektywy badań nad edukacja rodzajowa, WSHE, Łódź 2007, s. 49-58.

Pankowska D. (2008), Scenariusze godzin wychowawczych. Wychowanie a role ptciowe, GWP, Gdańsk.

Pankowska D. (2009a), Obraz systemu ról plciowych w polskich podręcznikach dla klas poczatkowych, [w:] L. Kopciewicz, E. Zierkiewicz (red.), Koniec mitu niewinności? Pteć i seksualność w socjalizacji i edukacji, ENETEIA, Warszawa, s. 29-67.

Pankowska D. (2009b), Czego uczeń dowiaduje się w szkole o ludziach? Ukryty program szkoły - cz. 3, „Psychologia w Szkole”, nr 1 (21), s. 37-47.

Pauluk D. (2006), Kontrowersje wokót wzorców socjalizacji kobiet w podręcznikach do wychowania seksualnego - próba poszukiwania kompromisowych rozwiazań, [w:] M. Chomczyńska-Rubacha (red.), Role ptciowe. Kultura i edukacja, WSHE, Łódź, s. $151-163$.

Pawlęga M. (2011a), Analiza oferty ksztatcenia w formie studiów podyplomowych, [w:] M. Abramowicz (red.), Wielka nieobecna - o edukacji antydyskryminacyjnej w systemie 
edukacji formalnej w Polsce. Raport z badań, Towarzystwo Edukacji Antydyskryminacyjnej, Warszawa, s. 36-41.

Pawlęga M. (2011b), Analiza oferty Ośrodka Rozwoju Edukacji (ORE), [w:] M. Abramowicz (red.), Wielka nieobecna - o edukacji antydyskryminacyjnej w systemie edukacji formalnej w Polsce. Raport z badań, Towarzystwo Edukacji Antydyskryminacyjnej, Warszawa, s. 42-59.

Pietryczuk B. (2011), Poglady dzieci i młodzieży na temat ról płciowych/rodzajowych oraz pojęcia kobiecości i męskości, „Przegląd Badań Edukacyjnych”, $\mathrm{nr} 2$

Radkiewicz M. (2002), Matki, żony i... feministki?! Serialowe wizerunki kobiet w kontekście polskiej kultury popularnej, [w:] E. Zierkiewicz, I. Kowalczyk (red.), Kobiety w kulturze popularnej, Konsola, Wrocław, s. 53-62.

Rozporzqdzenie Ministra Nauki i Szkolnictwa Wyższego w sprawie standardów ksztatcenia przygotowujacego do wykonywania zawodu nauczyciela z 12.01.2012 r.

Skowrońska A. (2004), Modele funkcjonowania kobiet i mężczyzn w podręcznikach wychowania do życia w rodzinie, [w:] M. Chomczyńska-Rubacha (red.), Pteć i rodzaj w edukacji, WSHE, Łódź, s. 203-210.

Stępień B., Synakiewicz A. (red.) (2008), Przeciwdziałanie przemocy i przemocy seksualnej wobec dziewczat. Poradnik dla nauczycielek i nauczycieli, Fundacja Feminoteka, Warszawa.

Szymczak M. (red.) (1978), Słownik języka polskiego, t. 1, PWN, Warszawa.

Szczepanik R. (2004), Nauczyciele wobec zachowan szkolnych uczniów i uczennic starszych klas szkoły podstawowej, [w:] M. Chomczyńska-Rubacha (red.), Pteć i rodzaj w edukacji, WSHE, Łódź, s. 93-107.

Szczepanik R. (2009), (Re)socjalizacja rodzajowa młodzieży nieprzystosowanej społecznie, [w:] L. Kopciewicz, E. Zierkiewicz (red.), Koniec mitu niewinności? Płeć i seksualność w socjalizacji i edukacji, ENETEIA, Warszawa, s. 161-179.

Szczepanik R. (2010), „Płeć” resocjalizacji. Typ narracji w kształceniu pedagogów resocjalizacyjnych, „Kultura i Edukacja”, pod red. M. Chomczyńskiej-Rubacha, nr 2, s. 80-92.

Świderska M., Lebiedzik M. (2004), Czy płód jest mężczyznq - ukryte przekazy dotyczqce płci w podręcznikach biologii, [w:] M. Chomczyńska-Rubacha (red.), Płeć i rodzaj w edukacji, WSHE, Łódź, s. 169-174.

Teutsch A. (2011), Analiza oferty placówek doskonalenia nauczycieli, [w:] M. Abramowicz (red.), Wielka nieobecna - o edukacji antydyskryminacyjnej $w$ systemie edukacji formalnej w Polsce. Raport z badań, Towarzystwo Edukacji Antydyskryminacyjnej, Warszawa, s. 72-90. 
Unger R., Saundra (2002), Seksizm: perspektywa zintegrowana, [w:] B. Wojciszke (red.), Kobiety i mężczyźni: odmienne spojrzenia na różnice, GWP, Gdańsk, s. 261-302.

Wielka nieobecna - o edukacji antydyskryminacyjnej w systemie edukacji formalnej $w$ Polsce. Raport z badań (2011), pod red. M. Abramowicz, Towarzystwo Edukacji Antydyskryminacyjnej, Warszawa.

Wołosik A. (2009), Spójrz w stronę dziewczat, [w:] L. Kopciewicz, E. Zierkiewicz (red.), Koniec mitu niewinności? Płeć i seksualność w socjalizacji i edukacji, ENETEIA, Warszawa, s. 219-235.

Wójtewicz A. (2009), „Dziwki”, „królowe” i „,szare myszki”, czyli gimnazjalna codzienność widziana przez pryzmat seksualizacji dziewczyństwa, [w:] L. Kopciewicz, E. Zierkiewicz (red.), Koniec mitu niewinności? Płeć i seksualność w socjalizacji i edukacji, ENETEIA, Warszawa, s. 119-141 .

Zamojska E. (2010), Równość w kontekstach edukacyjnych. Wybrane aspekty równości w polskich i czeskich podręcznikach szkolnych, UAM, Poznań.

Zierkiewicz E. (2004), Balansowanie na ,genderowej" linie. Nancy drew jako model roli dla dorastajacych dziewczynek. W: Pteć i rodzaj w edukacji, pod red. M. Chomczyńskiej-Rubacha, WSHE, Łódź, s.175-180.

Zierkiewicz E., Łysak A. (2006), „Harry Potter” i tradycyjny świat podziałów płciowych, [w:] Role ptciowe. Kultura i edukacja, pod red. M. Chomczyńskiej-Rubacha, WSHE, Łódź, s. 75-94. 